\title{
Cytokinins in cultivated champignon
}

\author{
ETELKA KOVÁCS
}

\begin{abstract}
KOVACS, E. 1978: Cytokinins in cultivated champignon. - Karstenia 18 (suppl.).
The cytokinins that were responsible for inhibiting ageing of plants were examined. It was found out that the cytokinin extract prepared from cultivated mushrooms inhibited the opening in the mushroom cap.

Upon the results of the identification tests carried out so far there are zeatin and dimethyallyladenine to be found in cultivated mushrooms. Identification of some more cytokinins and determining their activities, resp., is being in progress. Most of the cytokinins can be found in the gills of cultivated mushrooms.

Quantity of cytokinins decreases in the function of storage time.

E. Koväcs, Central Food Research Institute, Herman Ottő u. 15, H-1022 Budapest, Hungary.
\end{abstract}

\section{Introduction}

Since there very little is known about the physiology of mushrooms, especially about the post-harvest changes in them, we have found it necessary to start research work in this direction.

According to the results obtained, cytokinins stimulate the intensity of protein synthesis by increasing the nucleic acid synthesis: they are responsible for inhibiting ageing in plants.

Our aim is to determine the cytokinins in the different parts of mushrooms during storage.

Miller (1967) was the first to find three cytokinins in mycorrhyzal fungus. Two of these compounds were isolated in crystalline form from such media and were found to have properties identical to those of synthetic zeatin and zeatin riboside. Since then cytokinins have been found in a large part of the mushroom mycelia and fruiting bodies. For example, it can be found in the fruiting body of Rhizopogon roseolus (Pozsar 1968), of Coprinus micaceus (Szabó et al. 1970), of Calocybe georgii, Agaricus campester (Nada 1975) and of Agaricus bisporus (Szarvas \& Pozsár 1977). Several fungi, including six species of the genus Rhizopogon, 22 species of Hebslome and one of Agarious, have been screened for production of cytokinins. Species of Rhizopogon and 22 species of Hebezoma gave off detectable quantities of cytokinins and Agaricus bisporus was without activity. The negative results must be viewed with caution since cytokinin production might occur, but at levels too low to be detected with their procedure, or the fungus might produce some substance which inhibits the growth response of the soybean tissue (Crafts \& Miller 1974).

Material and methods

Raw material
The Agaricus bisporus used in the experiments was obtained from the DUNA Agricultural Co-operative, Budapest.

Cytokinins extraction procedures

Tissue $(50 \mathrm{~g})$ was blended with $80 \%$ ethanol three times the quantity of the sample. The homogenate was kept in the refrigerator overnight, then filtered. The filtrate was evaporated under vacuum (at $40^{\circ} \mathrm{C}$ ) and set at $\mathrm{pH} 3.5$. The concentrate was shaken with a fourfold volume of ether. The ether phase, being cytokinin inactive, was not used. The aqueous phase was set at $\mathrm{pH} 6.5$ and shaken with a fourfold volume of $n$ -butanol saturated with water. The butanol phase was evaporated under vacuum (at $40^{\circ} \mathrm{C}$ ) and was then purificated.

Purification of extract on insoluble polyvinylpyrrolidone (PVP) column

Polyclar AT (GAF), an insoluble form of PVP, forms insoluble complexes with phenols, which can thus be removed from plant extracts.

The column was prepared by pouring a slurry of Polyclar AT in distilled water into a $1.5 \times 30 \mathrm{~cm}$ column. It was allowed to settle and then washed thoroughly with distilled water followed by $M / 75$ phosphate buffer at $\mathrm{pH} 6.4$. Then $1-4 \mathrm{ml}$ of extract was applied to the column and which was then eluted with further phosphate buffer at $\mathrm{pH} 6.4$ and citrate buffer at $\mathrm{pH} 3.5$. The column flow rate was $35 \mathrm{ml} / \mathrm{h}$. The cytokinin elution profile was obtained by monitoring the transmittance of ultraviolet light at $254 \mathrm{~nm}$ through the eluate using an LKB Uvicord II absorptiometer (Biddington \& Thomas 1973a).

Amaranthus betacyanin bioassay for rapid determination of cytokinins in mushroom extracts 
The Amaranthus betacyanin assay is based on the cytokinin-induced formation of betacyanins in the cotiledons and hypocotils of $A$. caudatus seedlings incubated in the dark in the presence of tyrosine (Köhler \& Conrad 1966, Bigot 1968).

Seeds of Amaranthus caudatus L. (Samuel Dobie \& Son Ltd., Chester) were sown in 30 x $15 \mathrm{~cm}$ plastic boxes on two layers of Whatman 3 MM filter paper moistened with distilled water and allowed to germinate in darkness at $25^{\circ} \mathrm{C}$ for $96 \mathrm{~h}$. The seed coats were removed and explants consisting of the upper portion of the hypocotyl plus the cotyledons were cut from the seedlings. These explants were used as the bioassay sections, sets of ten being transferred to bioassay boxes ( $50 \mathrm{~mm}$ diam.). Each box contained two layers of Whatman 3 MM filterpaper moistened with $2 \mathrm{ml}$ of M/75 phosphate buffer at $\mathrm{pH} 6.4$ containing $1 \mathrm{mg} / \mathrm{ml}$ tyrosine and the cytokinin to be assayed. The boxes were incubated at $25^{\circ} \mathrm{C}$ for $18 \mathrm{~h}$ in the dark, after which the explants were removed and placed in $3 \mathrm{ml}$ of distilled water. Betacyanin was extracted by means of two cycles of freezing and thawing and the quantity was determined by calculating the difference between the optimal densities at $542 \mathrm{~nm}$ and $620 \mathrm{~nm}$ (Biddington \& Thomas 1973b).

\section{Results and conclusions}

The extract of the mushrooms was first separated with thin-layer chromatography and we found zeatin and 6 $-(\gamma-\gamma$-dimethyl-allylamino)purine (DMAA).

It was found that the extract of the gills inhibited the opening of the cap.

We tried to determine the activity of the extract of the gills with tobacco callus culture and carrot root tissue assay, but it was not successful. It is probable that an inhibitor factor or the phenolic compounds disturb these assays. PVP may be used as a highly efficient purifying agent during the extraction of plant hormones, because it strongly binds phenols. Purification was carried out according to the method of Biddington \& Thomas (1973a). The primary aim of purification was to remove substances of phenolic character. The extract was applied to the column and cytokinins were eluted with a phosphate buffer at $\mathrm{pH}$ 6.4 and then with a citrate buffer at $\mathrm{pH}$ 3.5. The elution profile of the extract of the primordium (0.5$1.0 \mathrm{~cm}$ ) can be seen in Fig. 1. The cytokinin content was insignificant.

In Fig. 2 can be seen the elution profile of the extract of flesh (cap without lamellae). On eluting the extract prepared from gills with a buffer at $\mathrm{pH} 6.4$ striking differences were observed depending on storage time. Fractions 7 to 13 are ninhydrin positive (Fig. 3). Elution with a buffer at $\mathrm{pH} 3.5$ is shown in Fig. 4. The reduction of the cytokinin content with storage time may be seen in this figure.

Because opening of the mushroom cap was inhibited by the gill extract, we began to investigate the biological activity of individual fractions of the eluate at $\mathrm{pH} 6.4$.
Fig. 1. Elution profile of the extract of the primordium.

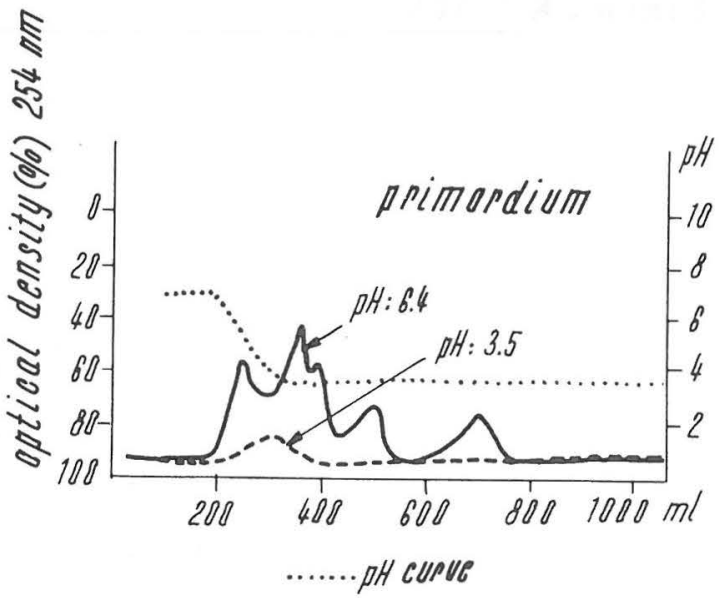

Fig. 2. Elution profile of the extract of the mushroom cap without lamellae.

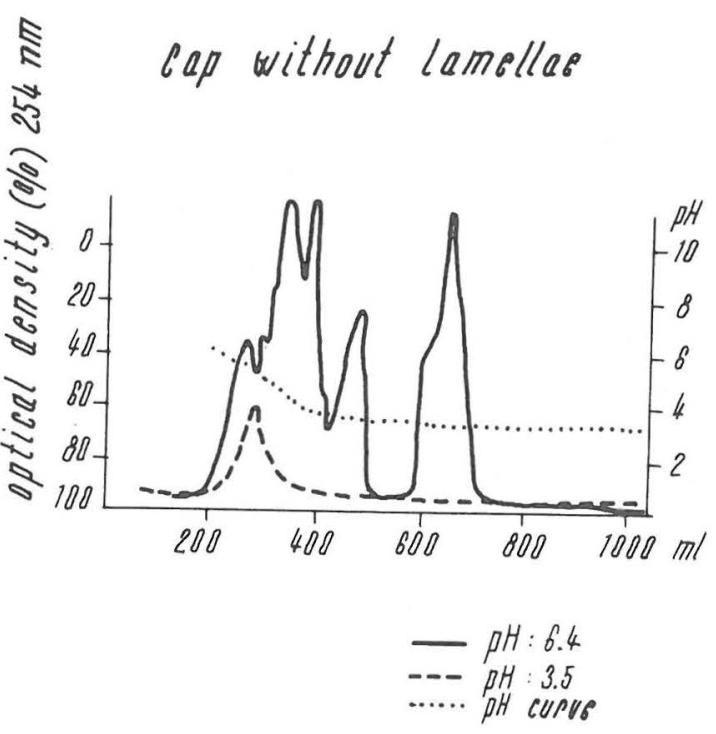

In Fig. 5 is seen the result of the Amaranthus betacyanin bioassay. There are five areas in it. Cytokinin activity cannot be found in the gills of mushrooms kept at $10^{\circ} \mathrm{C}$ and $95 \%$ relative humidity for two days (Fig. 6). The fractions at $\mathrm{pH} 3.5$ have not been examined as yet.

The thorough investigation of the biological activity of the individual fractions of the eluate and their effect upon the opening of the cap is the subject of our future study. The results will show 
Fig. 3. Elution profile of the extract of the gills at $\mathrm{pH} 6.4$.

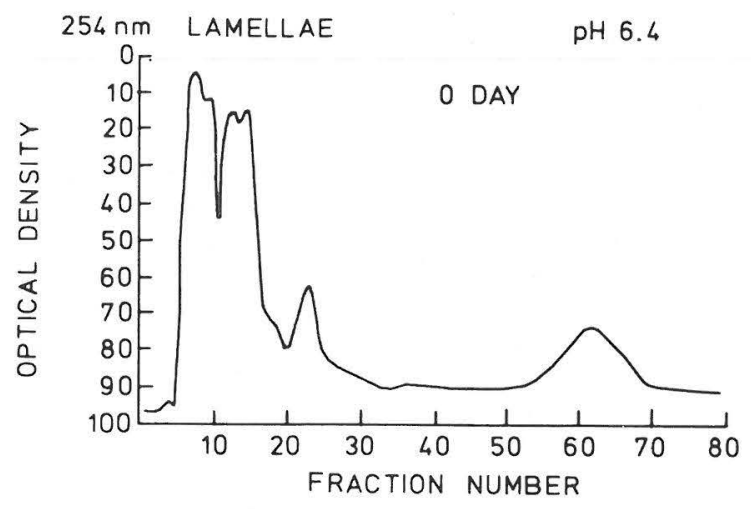

Fig. 4. Elution profile of the extract of the gills at $\mathrm{pH} 3.5$.

$\mathrm{pH} 3.5$
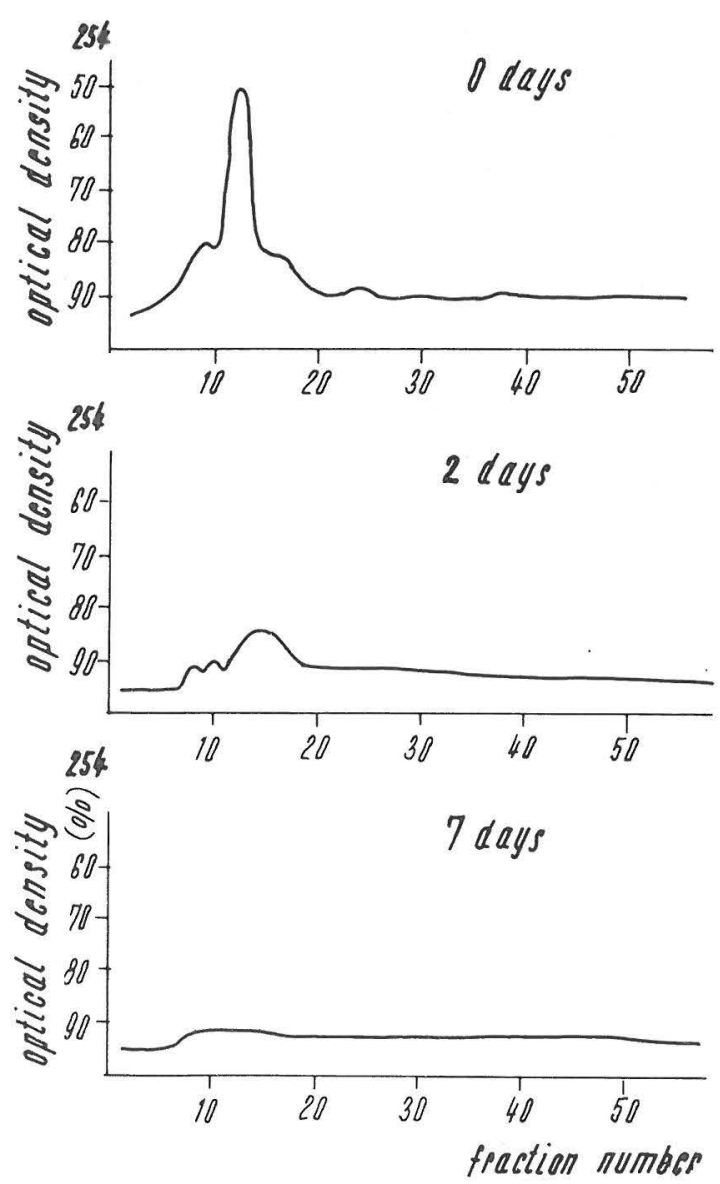

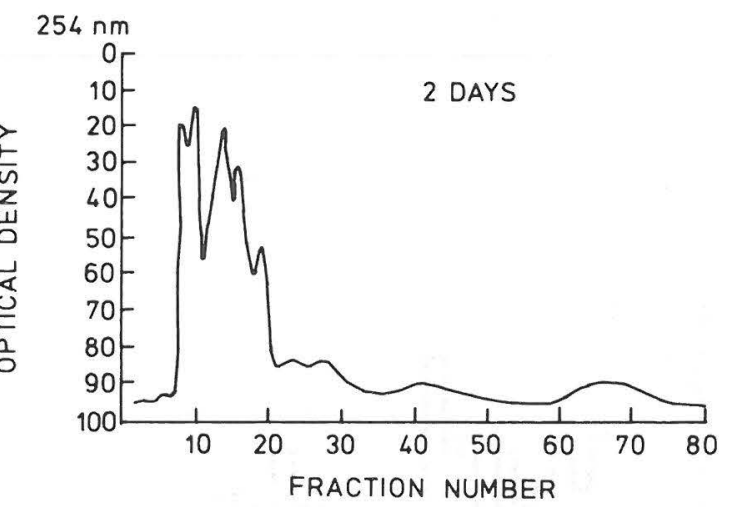

Fig. 5. Betacyanin production in seedlings of Amaranthus caudatus in the presence of extract of the gills.

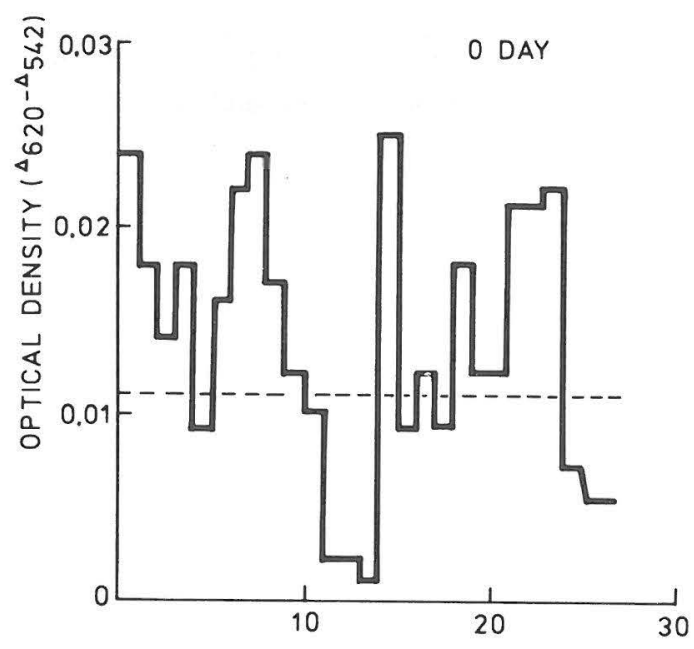

FRACTION NUMBER

whether cytokinins are really capable of inhibiting the ripening of mushrooms and opening of the cap. We should like to investigate the effect of ionizing radiation on the cytokinins in mushrooms and to study the cytokinin content and its changes in other edible mushrooms.

\section{$\underline{\text { References }}$}

Bigot, C. 1968: Action d'adenines substituées sur la synthèse des betacyanises dans la plantule d'Amaranthus caudatus L. Possibilité d'un test biologique de dosage des cytokinins.-C.R. Acad. Sci. (Paris) 266: 349-352. 
Fig. 6. Betacyanin production in seedlings of Amaranthus caudatus in the presence of extract of the gills. Mushrooms were stored at $10^{\circ} \mathrm{C}$ and at $95 \%$ relative humidity for 2 days.

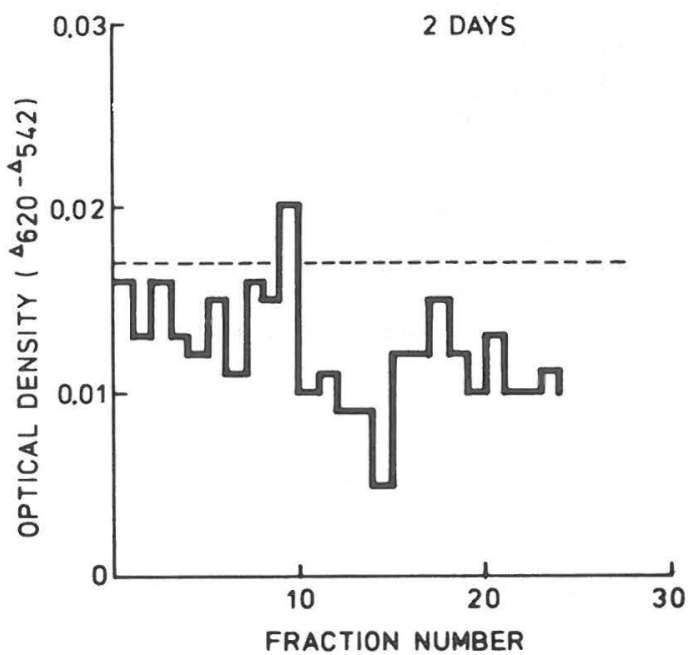

Biddington, N.L. \& Thomas, T.H. 1973a: Chromatography of five cytokinins on an insoluble polyvinylpyrrolidone column. - J. Chromatography 75: 122-123.

-" $\quad$ 1973b: A modified Amaranthus betacyanin bioassay for the rapid determination of cytokinins in plant extract. - Planta (Berl.) 111: 183-186.

Crafts, C.B. \& Miller, C.O. 1974: Detection and identification of cytokinins produced by mycorrhyzal fungi. - Plant Physiol. 54: 586-588.

Köhler, K.H. \& Conrad, K. 1966: Ein quantitativer Phytokinin Test. - Biol. Rundschau 4: 36-37.

Miller, C.0. 1967: Zeatin and zeatin riboside from a mycorrhizal fungus. - Science 157: 1055-1056.

Nada, G. 1975: Hormonalni vpliv gob Calocybe georgii Fr, in Agaricus campester Fr. na rast in razvoj trav v "Carovnißkem risu". - Biol. vestn. (Ljubljana) 23: 89-96.

Pozsár, B.I. 1968: Citokinek elöfordulása nagygombákban (Occurrence of cytokinins in higher fungi). - Mikológiai Közlemenyek 2:84.

Szabó, L. Gy., Pozsar, B.I. \& Kota, M. 1970: Cytokinin activity of the fruiting body of Coprinus micaceus Fr. - Acta Agronomica Acad. Sci. Hung. 19: 402-403.

Szarvas, T. \& Pozsár, B.I. 1977: Az NPN arányok és az endogén citokinin szintek közötti negativ összefüggés micéliumokban és levelekben. Magyar Mikrobiológiại Társaság Kongresszusa, Sopron, 1977, junius 17. 